\title{
Conceptions of Courts and Their Jurisdiction
}

In the summer of 1998, 160 States met in Rome to negotiate the drafting of what would become the Rome Statute of the International Criminal Court. After a month long of arduous horse-trading 120 States decided to adopt the Rome Statute. Pursuant to the Rome Statute, as adopted on 17 July 1998, the ICC has jurisdiction over genocide, crimes against humanity, war crimes and aggression. Except for the crime of aggression, ${ }^{1}$ the ICC was endowed to exercise jurisdiction over these crimes through three distinct channels: (1) State referral; (2) the prosecutor initiating an investigation proprio motu; and, (3) the SC referring a situation to the Prosecutor under Chapter viI of the UN Charter. ${ }^{2}$ The first two trigger mechanisms can be exercised only in situations where crimes were committed in the territory of a State party or by the national of a State party. ${ }^{3} \mathrm{~A}$ territorial or national State that is not party to the Rome Statute can still confer jurisdiction on the ICC by lodging a declaration with the Registrar of the ICC in which it "accept[s] the exercise of jurisdiction by the Court". ${ }^{4}$ In contrast, the third trigger mechanism Article 13 (b) - does not require the consent of either the territorial or national State, but only that the SC acts under Chapter VII of the UN Charter. ${ }^{5}$

There is, however, the view that "[i]t need not have been this way." ${ }^{\text {D }}$ Due to the nature of the crimes within the ICC's subject-matter jurisdiction, several States and scholars argued that the Court could have exercised universal jurisdiction. ${ }^{7}$ In any event, Article 13 (b) provides the ICC with universal jurisdiction - Article 13 (b) does not require the consent of either the territorial or national State. Neither the Statute nor the Court itself seem to make a clear distinction between cases that are triggered by the SC, States or by the Prosecutor-all cases are treated alike - as if the Statute applies to all since its entry into force. As it be will shown below, there is indeed a disagreement over the interpretation and application of the Rome Statute in situations triggered under Article 13 (b). At the heart of this disagreement is the question of

1 The crime of aggression will also be subject to these three trigger mechanisms as of 17 July 2018 , see Section 9 of this chapter.

2 Rome Statute, Art. 13-15.

3 Rome Statute, Art. 12.

4 Rome Statute, Art. 12 (3).

5 Rome Statute, Art. 13 (b).

6 Bekou and Cryer, "Universal Jurisdiction," 51.

7 See e.g. Kaul, "Preconditions,"; see sections 7-8.1 of this chapter for more details. 
whether Article 13 (b) symbolizes universal jurisdiction arising from the nature of the crimes within the jurisdiction of the ICC or whether it is a manifestation of the Chapter viI powers of the SC.

The notion of jurisdiction must to be clarified before proceeding further in our analysis. Indeed, this term is at the heart of the concept identified and is used differently in various contexts and thus understood in many divergent ways. In the following sections we will first describe the 'types' of jurisdiction. Secondly, we will differentiate the 'types' of jurisdiction from the 'heads' of jurisdiction. Thirdly, the historical evolution of international criminal law and international criminal jurisdiction from post-World War II trials to the establishment of the ICC will be addressed in relation to the notion of delegation of jurisdiction. Fourthly, against this background the two 'conceptions' of our 'concept' will be briefly described. Fifthly, the amendments to the Rome Statute adopted from 2010 onwards are touched upon with a view to determine whether they affect our two conceptions of a referral under Article 13 (b).

\section{$\mathbf{1}$ \\ Types of Jurisdiction}

The jurisdiction of a State, in the present context, "refers to its authority under international law to regulate the conduct of persons, natural and legal, and to regulate property in accordance with its municipal law." ${ }^{\prime}$ The jurisdiction of a State can be criminal or civil; only the criminal jurisdiction of States will be considered in this book. Three 'types' of jurisdiction can be distinguished: jurisdiction to prescribe, jurisdiction to adjudicate and jurisdiction to enforce. ${ }^{9}$ Jurisdiction to prescribe refers to the authority of a State to prescribe rules. Jurisdiction to adjudicate refers to "the rights of Courts to receive, try and determine cases referred to them." ${ }^{10}$ Many believe it is not necessary to separate this type of jurisdiction from jurisdiction to enforce. ${ }^{11}$ However as we will see international criminal tribunals adjudicate cases but generally lack enforcement powers. ${ }^{12}$ Jurisdiction to enforce

8 O'Keefe, "Universal Jurisdiction," 736.

9 Ibid, at 736 .

$10 \quad$ Lowe and Staker, "Jurisdiction," 317.

11 O'Keefe, "Universal Jurisdiction," 736; Lowe and Staker, "Jurisdiction," 317; Williams, Jurisdictional Issues, 11-13.

12 See e.g. Cassese, "Current Trends", 10-12; Sadat, Transformation of International Law, 12O122. The international tribunals and courts do not have their own police forces, they entirely rely on States to enforce their orders, arrest warrants, judgments, orders to seize assets, sentences, etc, see Chapter 5 , section 4 . 
refers to the authority of a State to enforce the rules it has prescribed and adjudicated. These are 'types' of jurisdiction.

\section{$2 \quad$ Heads of Jurisdiction}

Jurisdiction to prescribe is not territorially limited; depending on the category of crimes it can also be exercised based on the active and passive nationality principles, protective principle, and universality principle. ${ }^{13}$ According to O'Keefe's terminology, these principles constitute 'heads' of jurisdiction. ${ }^{14}$ The most important 'head' of jurisdiction is territoriality. Territorial jurisdiction is the authority of a State to exercise jurisdiction over acts committed on its territory. To put it simply, territorial jurisdiction as a 'head' of jurisdiction is based on the principle of territorial integrity. This 'head' of jurisdiction is unquestionably available to States to exercise any 'type' of jurisdiction, i.e. jurisdiction to prescribe, adjudicate and enforce. The nationality of the offender, or the so-called active nationality, is, after territoriality, the most widely accepted head of jurisdiction..$^{15}$ Another head of jurisdiction based on nationality is the passive personality principle which gives a State jurisdiction over crimes committed against its nationals. ${ }^{16} \mathrm{~A}$ further head of jurisdiction is the protective principle. The protective principle as a head of jurisdiction gives a State jurisdiction over acts committed against the "essential interest of the State". ${ }^{17}$ The example par excellence for the protective principle is the counterfeiting of currency. ${ }^{18}$ Finally, universal jurisdiction, or the so-called universality principle, is the jurisdiction of States irrespective of the place of perpetration, the nationality of the suspect or the victim.

In contrast to the protective principle, the universality principle is jurisdiction over acts committed not against any State itself but against the

13 Lotus (SS) Case (France v Turkey,) Permanent Court of International Justice (PCIJ), PCIJ Rep Series A No 9, p. 20, 7 September 1927 (hereinafter Lotus Case); Ryngaert, Jurisdiction, 24 .

14 O'Keefe, "Universal Jurisdiction," 738.

15 Arnell, "Nationality-Based Jurisdiction," Quarterly 955; Williams, Jurisdictional Issues, 12.

16 See Case Concerning the Arrest Warrant of 11 April 2000 (Democratic Republic of the Congo v. Belgium) International Court of Justice, Judgment, I.C.J. Reports 2002, 14 February 2002, (hereinafter Arrest Warrant Case), Joint separate opinion of Judges Higgins, Kooijmans and Buergenthal, par. 47; See also Separate opinion Judge Rezek, par. 5; Separate opinion President Guillaume, par. 4.

17 Lowe and Staker, "Jurisdiction," 325.

18 The Charter and Judgment of the Nürnberg Tribunal - History and Analysis: Memorandum submitted by the Secretary-General, 1949, UN Doc. A/CN.4/5, at 8 o. 
international community as a whole. ${ }^{19}$ Under the head of universal jurisdiction, there is no nexus between the State in question and the act, except that the nature of the act makes the perpetrator a hostis humani generis. ${ }^{20}$ Grotius asserted that every State has jurisdiction over "gross violations of the law on nature and of nations, done to other States and subjects". Piracy was for many years the only crime giving rise to universal jurisdiction, not because it was a heinous act but because it is committed outside the territorial jurisdiction of all States. ${ }^{21}$ More recently many States have recognized crimes such as genocide, ${ }^{22}$ crimes against humanity, ${ }^{23}$ war crimes ${ }^{24}$ and torture ${ }^{25}$ as capable of triggering universal jurisdiction. ${ }^{26}$ The views are divided with respect to the crime of aggression, albeit at least 10 States assume universal jurisdiction over this crime in their domestic legislation. ${ }^{27}$

The various 'types' of jurisdiction available to States cannot be exercised in respect of all 'heads' of jurisdiction. In 1927, the Permanent Court of International Justice (PCIJ) held in the Lotus Case that "all that can be required of a State is that it should not overstep the limits which international law places

19 Luban, "Fairness to Rightness," 3.

$20 \quad$ Grotius, De jure belli ac pacis, 247.

21 Luban, "Fairness to Rightness," 2.

22 The Genocide Convention does not provide for universal jurisdiction, Convention on the Prevention and Punishment of the Crime of Genocide (Dec. 9, 1948), 78 U.N.T.S,277, Art .6 (hereinafter Genocide Convention). Nevertheless, it is considered as giving rise to universal jurisdiction under customary international law, see Morris, "Universal Jurisdiction," 347 .

23 See e.g. Eichmann Appeal Judgment.

24 At least the Grave Breaches of the Geneva Convention, Geneva Convention for the amelioration of the condition of the wounded and sick in armed forces in the field (Aug. 12, 1949), 75 U.N.T.S. 970, Art. 49 (Geneva Convention I); Geneva Convention for the amelioration of the condition of the wounded, sick and shipwrecked members of the armed forces at sea (Aug. 12, 1949), 75 U.N.T.S. 971, Art. 50 (Geneva Convention II); Geneva Convention relative to the treatment of prisoners of war (Aug. 12, 1949), 75 U.N.T.S. 972, Art. 129 (Geneva Convention III); Geneva Convention relative to the protection of civilian persons in time of war (Aug. 12, 1949), 75 U.N.T.S. 973, Art. 146 (Geneva Convention IV); Geneva Protocol I Additional to the Geneva Conventions of 12 August 1949, and Relating to the Protection of Victims of International Armed Conflicts (June 8, 1977) 1125 U.N.T.S. 3, Art. 85, 86, 88 (Additional Protocol I); for war crimes committed in non-international armed conflict see Kaul and Kress, "Jurisdiction and Cooperation," 148-150.

25 See Pinochet No. 3; Filartiga v. Pena-Irala, 63o F. 2 d 876 (2d Cir.198o).

26 See ILC 1996 Draft Code of Crimes Against the Peace and Security of Mankind, UN doc. A/51/10, p. 28; Tadic Interlocutory Appeal Decision, par. 62; Prosecutor v. Ntuyahaga, Case No. ICTR-98-4O-T, Decision on Prosecution Motion to Withdraw the Indictment (March 18 , 1999).

27 See McDougall, The Crime of Aggression, 318. 
upon its jurisdiction; within these limits, its title to exercise jurisdiction rests in its sovereignty." 28 The sovereign principle as expressed by Lotus is that a sovereign State may act in any way it wishes so long as it does not contravene an explicit prohibition. ${ }^{29}$ This is not the place to discuss whether the dictum in Lotus remains applicable today or whether it has been entirely reversed. ${ }^{30}$ Suffice to say that it is generally recognized that as regards jurisdiction to prescribe, States may exercise their criminal jurisdiction on the basis of various heads as long as there is sufficient link between the conduct in question and the interest of the State. ${ }^{31}$ Indeed, the PCIJ held that "the territoriality of criminal law $[. .$.$] is not an absolute principle of international law and by no means$ coincides with territorial sovereignty". ${ }^{32}$ This concerned prescriptive jurisdiction. On the other hand, as Ryngaert observes, "[t] erritorial sovereignty would relate to enforcement jurisdiction." 33 Jurisdictions to adjudicate and to enforce are territorial, unless consent from the extraterritorial State is given. ${ }^{34}$ Thus, in order to adjudicate and enforce its criminal law extraterritorially a State needs the consent of the territorial State; otherwise, it impinges on the territorial sovereignty of the latter State. ${ }^{35}$

\section{Delegation of Jurisdiction}

A State may delegate its head of jurisdiction to another State or to an international tribunal. ${ }^{36}$ Indeed, a State can confer its territorial, active nationality, passive nationality, protective and universal jurisdiction to another State or to an international tribunal. ${ }^{37}$ These 'heads' of jurisdiction indicate the 'basis' of

28 Lotus Case, par. 19.

29 Reydams, Universal Jurisdiction, 14.

$3^{\circ}$ In contrast to the position taken in Lotus it is generally held that in order to exercise extraterritorial jurisdiction a State needs to show the permissive rule. Such approach is adopted in Harvard Research on International Law, Draft Convention on Jurisdiction with Respect to Crime; see also Ryngaert, Jurisdiction, 26-31; Reydams, Universal Jurisdiction, 14-21.

31 If these are lacking, the jurisdiction may be called exorbitant, see Chapter 2.

32 Lotus Case, p. 20.

33 See Ryngaert, Jurisdiction, 24.

34 See Lotus Case, p. 18-19.

35 See O'Keefe, “Universal Jurisdiction,” 740.

36 See Akande, "Nationals of Non-Parties," 622-634; Scharf, "Nationals of Non-Party States," 98-110; Danilenko, "Third States," 465; Williams, Jurisdictional Issues, 300-314; Sadat and Carden, “An Uneasy Revolution," 412-413; contra Morris, "High Crimes," 52.

Ibid. 
the jurisdiction conferred on the other State or on the international tribunal. For the sake of clarity, instead of using 'head' of jurisdiction, we will use the term 'basis' of jurisdiction when a State delegates its right to exercise jurisdiction. In situations of transfer of jurisdiction, the State or international tribunal to which jurisdiction has been delegated remains bound to respect the same limits to its jurisdiction as the delegating State. ${ }^{38}$ Thus, one may ask: since jurisdiction to adjudicate and to enforce are restricted territorially, under which basis of jurisdiction do international criminal bodies act? An inquiry into the legal basis of some international criminal jurisdiction may elucidate under which jurisdictional basis their authority to prescribe, adjudicate and enforce derives from.

On 8 August 1945, the United States, Great Britain, the Soviet Union and France signed the Agreement for the Prosecution and the Punishment of the Major War Criminals of the European Axis (London Agreement) to which the Charter of the International Military Tribunal (Nuremberg Charter) was annexed. ${ }^{39}$ In this manner the Allies "acting in the interests of all the United Nations"40 established the International Military Tribunal (IMT or Nuremberg Tribunal) "for the trial of war criminals whose offenses have no particular geographical location".41 The Nuremberg Tribunal had jurisdiction over crimes against peace, crimes against humanity and war crimes. ${ }^{42}$ The basis of the jurisdiction of the Nuremberg Tribunal has been the subject of great debate within legal literature. ${ }^{43}$ Indeed, the Nuremberg Tribunal was based on a treaty between the four Allied Powers which conferred jurisdiction over territory and nationals of Germany without the formal consent of Germany. Like for the ICC, the 'concept' at stake is the exercise of jurisdiction over the territory and nationals of a State not party to the treaty establishing the tribunal.

38 Nemo dat quod non habet; Williams, Jurisdictional Issues, 408-409.

39 Agreement for the Prosecution and Punishment of the Major War Criminals of the European Axis and the Charter of the International Military Tribunal annexed thereto, (Aug. 8, 1945) 82 U.N.T.S. 279 (hereinafter (London Agreement)).

$40 \quad$ London Agreement, Preamble.

41 London Agreement, Art. 1.

42 Nuremberg Charter, Art. 6.

43 Scharf, "Nationals of Non-Party States," 103-105; Schwelb, "Crimes Against Humanity," 208; Morris, "High Crimes," 13. 
Addressing the propriety of the arrangement made by the Allies, the Tribunal stated:

The making of the Charter is the exercise of the sovereign legislative power by the countries to which the German Reich unconditionally surrendered; and the undoubted right of these countries to legislate for the occupied territories has been recognized by the civilized world [...] The signatory Powers created this Tribunal, defined the law it was to administer, and made regulations for the proper conduct of the Trial. In doing so, they have done together what any one of them might have done singly; for it is not to be doubted that any nation has the right thus to set up special courts to administer law. ${ }^{44}$

This statement spawned a debate about the jurisdictional basis and the legal character of the Nuremberg Tribunal. While some argued that the Nuremberg Tribunal was exercising universal jurisdiction delegated by the 'signatory Powers,', 45 others argued it was exercising national and territorial jurisdiction based on the sovereign consent of Germany as expressed "by the countries to which the German Reich unconditionally surrendered" ${ }^{46}$ Furthermore, the latter group claimed that the Nuremberg Tribunal was a joint municipal tribunal ${ }^{47}$ whilst the former claimed that the IMT was an international tribunal. ${ }^{48}$ For those who had a conception of the Nuremberg Tribunal as an international judicial body, its legal character mostly entailed that its basis of jurisdiction was universal jurisdiction. ${ }^{49}$ Each of the signatory powers had delegated its universal jurisdiction over the crimes to the Tribunal. Thus, by establishing the Tribunal "they have done together what any of them might have done singly" 50 For those who had a conception of the Nuremberg Tribunal as a joint municipal tribunal, like Georg Schwarzenberger, the Allies were co-sovereigns of Germany and they handled the Nuremberg Tribunal in that capacity. ${ }^{51}$ Indeed, it was assumed that the Allies as occupying powers

44 Trial of the Major War Criminals before the International Military Tribunal, vol. I, Nürnberg, 1947, at 223 (hereinafter Nuremberg Judgment).

45 Scharf, "Nationals of Non-Party States," 103-106; Schwelb, "Crimes Against Humanity," 208; Woetzel, The Nuremberg Trials, 87-89; Randall, “Universal Jurisdiction," 804-8o6.

46 Morris, "High Crimes," 37-42; Schwarzenberger, "The Judgment of Nuremberg", 170; Kelsen, "The Legal Status of Germany," 518.

47 Schwarzenberger, "The Judgment of Nuremberg", 170; Wright, "Nuremberg Trial," 330-333.

48 Schwelb, "Crimes Against Humanity," 149-152; Kelsen, "Judgment in the Nuremberg Trial," 286-288.

49 Schwelb, "Crimes Against Humanity," 149-152; Kelsen, "Judgment in the Nuremberg Trial," 286-288.

$50 \quad$ Nuremberg Judgment, at 223.

51 Schwarzenberger, "The Judgment of Nuremberg", 170. 
of Germany consented in their capacity as the Government of Germany to the Nuremberg Charter and thereby conferred jurisdiction to the Tribunal on the basis of the territorial and active nationality principles. ${ }^{52}$

The UN Secretary General in its 1949 Report on the Nuremberg Tribunal confirmed that the meaning of "had done together what any one of them might have done singly" can be interpreted as supporting the universal jurisdiction conception as much as the sovereign consent conception. ${ }^{53}$ The indeterminacy concerning the legal basis under which the Nuremberg Tribunal exercised jurisdiction persists to this day.

The same 'concept' as for the Nuremberg Tribunal applies in respect of the trials conducted under Control Council Law No. 10 - absence of formal consent of the German State to the law establishing the Tribunals-and thus the same conceptions resurge. ${ }^{54}$ Indeed, the Control Council Law No. 10 trials did not appeal to their 'sovereign legislative power' only; they also relied in some cases on the universality principle..$^{55}$ For instance, in the Hostage case, the military tribunal relied on universal jurisdiction to assert authority over the defendants who were accused of war crimes. ${ }^{56}$ The Hostage tribunal opinion was not uncontroversial but found support in other judgments of the military tribunals. In Justice, Judge Blair declared-reminding us of the debated Nuremberg Tribunal statement-that "the Allied Powers, or either of them, have the right to try and punish individual defendants in this case." ${ }^{57}$ The majority in Einsatzgruppen added that

[t]here is no authority which denies any belligerent nation jurisdiction over individuals in its actual custody charged with violation of international law. And if a single nation may legally take jurisdiction in such instances, with what more reason may a number of nations agree, in the interest of justice, to try alleged violations of the international code of war? ${ }^{58}$

52 See Schwarzenberger, "The Judgment of Nuremberg", 170; Wright, "Nuremberg Trial," 330333; Kelsen, "Judgment in the Nuremberg Trial," 286-288.

53 The Charter and Judgment of the Nürnberg Tribunal - History and Analysis: Memorandum submitted by the Secretary-General, 1949, UN Doc. A/CN.4/5, at 79-80; see also Morris, "High Crimes," 41.

54 See e.g. United States of America v Josef Altstoetter et al. (Justice), Tribunal War Crimes III, p. 958; see also Ministries, Order, 29 Dec. 1947, XV TwC 325; see Heller, The Nuremberg Military Tribunals, 112. Von Knieriem, The Nuremberg Trials, 97, 100.

55 Carnegie, "Jurisdiction," 418; However see Heller, The Nuremberg Military Tribunals, 134.

$5^{6}$ United States of America v Wilhelm List et al. (Hostage), XI TWC 1241.

57 United States of America v Josef Altstoetter et al. (Justice), Blair Separate Opinion, III TWC 1194; see Scharf, "Nationals of Non-Party States," 103-106.

$5^{8}$ United States of America v Otto Ohlendorf (Einsatzgruppen), IV TwC 46o. 
Other instances where the universality conception was adopted are the Hadamar, ${ }^{59}$ Zyklon $B^{60}$ and Kesselring cases. ${ }^{61}$

The International Military Tribunal for the Far East (Tokyo Tribunal) appears less contested as to its jurisdictional basis. Indeed, the Tokyo Tribunal was acting with the consent of the Japanese who had formally signed an instrument of surrender. Unlike the IMT, the sovereign consent conception seems to be the most commonly adopted position regarding the legal basis of the Tokyo Tribunal. Nevertheless, the Chief of Prosecution ${ }^{62}$ and dissenting Judge Bernard ${ }^{63}$ advanced the argument that the basis upon which the Tokyo Charter was created was a general right to enforce international criminal law. ${ }^{64}$ Hence, even though Japan gave its consent to the making of the Tokyo Tribunal Charter and jurisdiction, the Tokyo Tribunal gave rise to the same universalist propositions with regard to its jurisdictional basis than the Nuremberg Tribunal and the trials conducted under Control Council Law No. 10.

\section{The Nuremberg Principles and the Work of} the International Law Commission

Following the Nuremberg judgment the UN General Assembly adopted Resolution 95 (1) on the Affirmation of the Principles of International Law Recognized by the Charter of the Nuremberg Tribunal. ${ }^{65}$ In order to have these principles firmly established in international law and thoroughly defined, the General Assembly requested the International Law Commission (ILC) on 21 November 1947 to formulate the Nuremberg principles and to prepare a Draft Code of Offences against the Peace and Security of Mankind. ${ }^{66}$ The ILC

59 Law Reports of Trials of War Criminals, Vol. 1, Case 4, at 46, Trial of Alfons Klein et al., United States Military Commission Appointed by the Commanding General Western District, U.S.F.E.T., Wiesbaden, Germany, 8-15th October 1945.

6o Law Reports of Trials of War Criminals, Vol. 1, Case no. 9, Trial of Bruno Tesch and two Others, British Military Court, Hamburg, 1-8th March 1946.

61 Law Reports of Trials of War Criminals, vol. 8., Case No. 44, at 9, The Trial of Albert Kesselring British Military Court at Venice, Italy, 17 February-6 May 1947.

62 Keenan and Brown, Crimes against International Law, 18.

63 Dissenting Judgment of the Member from France of the International Military Tribunal for the Far East, p. 2.

64 Boister and Cryer, The Tokyo International Military Tribunal, 31.

65 General Assembly Resolution 95 (I) of 11 December 1946, Affirmation of the Principles of International Law recognized by the Charter of Nürnberg Tribunal, UN Doc. A/236.

66 General Assembly resolution 177 (II) of 21 November 1947, Formulation of the Principles Recognized in the Charter of the Nurnberg Tribunal and in the Judgment of the Tribunal, UN Doc. A/RES/177(II). 
submitted its formulation of the Nuremberg principles in $1950^{67}$ and adopted two draft codes in 1950 and $1954 .{ }^{68}$ On 9 December 1948, the General Assembly invited the ILC "to study the desirability and possibility of establishing an international judicial organ for the trial of persons charged with genocide or other crimes over which jurisdiction will be conferred upon that organ by international conventions". ${ }^{69}$ This project was in line with Article VI of the 1948 Genocide Convention which referred to a (future) "international penal tribunal." 70

The ILC appointed two Special Rapporteurs-Ricardo J. Alfaro and Emil Sandström-to draft working papers on the question of the desirability and possibility of establishing an international judicial organ. ${ }^{71}$ Alfaro submitted in his report that it was both desirable and possible to establish an international criminal jurisdiction. ${ }^{72}$ One objection to the creation of an international criminal jurisdiction that Alfaro recognized as worthy of consideration was the question of sovereignty. Indeed, States objected that to relinquish their domestic criminal jurisdiction was contrary to the traditional principle of sovereignty. Alfaro considered that there were two counterarguments to what he referred to as the "absolute sovereignty" objection. First, crimes against peace, war crimes, crimes against humanity and genocide are perpetrated by Governments or by individuals as representatives of Governments. Thus, their repression by territorial courts is so improbable that only an international criminal court could properly try these international crimes. Second, absolute sovereignty is incompatible with the UN's existence and functioning. Sates had to accept that a part of their sovereignty had been relinquished to the UN. Thus, Alfaro considered that the UN should create such international criminal jurisdiction. ${ }^{73}$

On the other hand, Emil Sandström submitted in his report that an international criminal jurisdiction would be ineffective and therefore undesirable. ${ }^{74}$

67 ILC, Principles of International Law recognized in the Charter of the Nürnberg Tribunal and in the Judgment of the Tribunal, with commentaries, UN Doc. A/1316 (1950).

68 The Code was originally titled a code of offences: the change from 'offences' to 'crimes' was made by General Assembly Resolution 42/151 of 7 December 1987, UN Doc. A/42/49.

69 General Assembly Resolution 26o B (III) of 9 December 1948, Study by the ILC of the Question of an International Criminal Tribunal, Doc. A/RES/3/26o B.

70 Genocide Convention, Art. 6; The ILC request and the Genocide Convention were adopted during the same General Assembly plenary meeting.

71 ILC, Report of the ILC on the Work of its First Session, UN Doc. A/925 (A/4/10), par. 32-34.

72 ILC, Report on the Question of International Criminal Jurisdiction by Ricardo J. Alfaro, Special Rapporteur, Doc. A/CN.4/15 and Corr.1 (1950).

73 Ibid., at 17.

74 ILC, Report on the Question of International Criminal Jurisdiction by Emil Sandström, Special Rapporteur, Doc. A/CN.4/20 (1950). 
According to the Special Rapporteur, too many States considered that the repression of crimes was a matter within the competence of the State and not a matter to be dealt with by the international community. ${ }^{75}$ Thus, Sandström did not recommend the establishment of an international criminal jurisdiction until the attitude of States in this regard changed.

The two Special Rapporteurs agreed that delegation of criminal jurisdiction was a necessary element for the establishment of an international criminal jurisdiction. However, while Alfaro was optimistic that the community of States would create such jurisdiction, Sandström believed States were too jealous of their adjudicative and enforcement jurisdiction to delegate them to an international body. The ILC discussed the reports presented by Alfaro and Sandström and decided by eight votes to one, with two abstentions, that the establishment of an international judicial organ was desirable and possible. ${ }^{76} \mathrm{On}$ the base of the ILC report, the General Assembly tasked a committee to draft a Statute for an International Criminal Court. ${ }^{77}$ However, the special committee submitted two reports which reflected the increasing reluctance of the international community regarding the establishment of an international criminal jurisdiction. ${ }^{78}$

On 4 December 1954, the General Assembly asked for a draft definition of aggression to be submitted to it. ${ }^{79}$ This last request saw the early progress of the ILC succumb to the paralysis of the Cold War. The General Assembly considered that the Draft Code of Offenses against the Peace and Security of Mankind and the Draft Statute for an International Criminal Court be postponed until a draft definition of aggression was submitted. ${ }^{80}$ Hence, until 1981 the process of drafting the Draft Code of Offences against the Peace and Security of Mankind and establishing an international criminal jurisdiction was blocked.

75 Ibid., at 21 .

76 ILC, Report of the ILC on its Second Session, UN Doc. A/1316 (1950).

77 General Assembly Resolution 489 (v) of 12 December 1950, International Criminal Jurisdiction, UN Doc. A/RES/5/489.

78 See Official Records of the General Assembly, Seventh Session, Supplement No. 11, UN Doc. A/2136; See Official Records of the General Assembly, Ninth Session, Supplement No. 12, UN Doc. A/2645.

79 General Assembly Resolution 895 (IX) of 4 December 1954, Question of Defining Aggression, UN Doc. A/RES/9/895.

8o General Assembly Resolution 897 (IX) of 4 December 1954 Question of Defining Aggression, UN. Doc. A/RES/9/895; General Assembly Resolution 898 (IX) of 14 December 1954, International Criminal Jurisdiction, UN Doc. A/RES/9/898. 
Around the same time as domestic proceedings against perpetrators of crimes committed during World War II was resurging, the General Assembly by Resolution 36/106 of 10 December 1981 invited the ILC to resume its work in elaborating the Draft Code of Offences against the Peace and Security of Mankind, which would become the Draft Code of Crimes Against the Peace and Security of Mankind (Draft Code of Crimes). ${ }^{81}$ The drafting of the Code of Crimes again raised the problem of its implementation and the various possible options: system of territoriality, system of personality, universal system and system of international criminal jurisdiction. ${ }^{82}$ The Draft Code of Crimes was concluded on first reading in 1991, but it was generally viewed plethoric and inadequate. ${ }^{83}$ This led some to express their preference for the question of an international criminal jurisdiction being examined separately from the project of the Draft Code of Crimes. ${ }^{84}$

In 1992 the ILC commenced work substantially on a Draft Statute for an International Criminal Court. ${ }^{85}$ In 1994 a Draft Statute was adopted and recommended to the General Assembly. ${ }^{86}$ The ILC Draft Statute was modest and limited in its scope. The Statute of the proposed court aimed to be primarily "procedural and adjectival". 87 The envisaged international criminal court was provided with jurisdiction over (1) genocide; (2) aggression; (3) serious violations of the laws and customs applicable in armed conflict; (4) crimes against humanity; and (5) crimes, established under or pursuant to the treaty provisions listed in the Annex to the Statute. However, the court had 'inherent jurisdiction' only over the crime of genocide. ${ }^{88}$ The principle of 'ceded jurisdiction'

81 General Assembly Resolution 36/106 of 1o December 1981, Draft Code of Offences against the Peace and Security of Mankind, UN Doc. A/RES/36/106.

82 ILC, Report of the ILC on the Work of its Thirty-Fifth Session, UN. Doc. A/38/10 (1983); ILC, Report of the ILC on the Work of its Thirty-Eighth Session, UN Doc. A/41/10 (1986).

83 See Commentaries on the International Law Commission's 1991 Draft Code of Crimes against the Peace and Security of Mankind (1993).

84 Crawford, "The Work of the International Law Commission," 24.

85 See ILC, Report of the Working Group on the Question of an International Criminal Jurisdiction, UN Doc. A/CN.4/L.471 (1992), par. 99.

86 See ILC, Draft Statute for an International Criminal Court, with commentaries UN Doc. A/49/10 (1994), par. 91.

87 See Ibid, at 36 .

88 Even though the ILC used the term "inherent" jurisdiction, it meant "that the court ought, exceptionally, to have inherent jurisdiction over it by virtue solely of the States participating in the Statute, without any further requirement of consent or acceptance by any particular State." However, the State making the complaint needs to be a party to the Convention on Genocide and to the Statute of the Court. See ILC, Draft Statute for an International Criminal Court, with Commentaries, UN Doc. A/49/10 (1994), Art. 21 (1) (a). 
was the 'guiding star' for the rest of the crimes within the subject-matter jurisdiction of the Court. ${ }^{89}$

The principle of 'ceded jurisdiction' meant that the international criminal jurisdiction would only proceed if the custodial and the territorial States had ceded their jurisdiction to the Court. ${ }^{90}$ In other words, the Court was envisaged as a facility available to States who wished to delegate their jurisdiction over a situation to the international court. On the other hand, the Court would not seek whether jurisdiction was 'ceded' if it gained jurisdiction over the matter as a consequence of a referral by the SC acting under Chapter VII of the UN Charter. ${ }^{91}$ In its commentary, the ILC wrote:

The Commission felt that such a provision was necessary in order to enable the Council to make use of the court, as an alternative to establishing ad hoc tribunals and as a response to crimes which affront the conscience of mankind. On the other hand, it did not intend in any way to add to or increase the powers of the Council as defined in the Charter, as distinct from making available to it the jurisdiction mechanism created by the statute.

The Draft Statute of the International Criminal Court was submitted to the General Assembly in November $1994 \cdot{ }^{92}$ In the General Assembly most delegations endorsed the establishment of a permanent international criminal court. The SC had only recently created an ad hoc tribunal for the Former Yugoslavia and was being pressed to create a second ad hoc tribunal to prosecute those responsible for genocide and other serious violations of international humanitarian law in Rwanda.

The Ad Hoc Tribunals

On 6 October 1992, the SC established a commission of experts to investigate violations of international humanitarian law in the former Yugoslavia. ${ }^{93}$ The

\footnotetext{
89 See ibid., at 36 , fn concerning the "inherent" jurisdiction over Genocide.

90 Ibid.

91 See ILC, Draft Statute for an International Criminal Court, Art. 23.

92 At the 49th session of the General Assembly it was decided that the ILC Draft Code would be considered during the 5 oth session but that first an ad hoc committee for the Establishment of an International Criminal Court needed to be set up, see UN Doc. A/C.6/49/L.24. SC Res. 780 (1992) of 6 October 1982, establishing a Commission of Experts to Examine and Analyze Information Submitted Pursuant to Resolution 771, UN Doc. S/RES/78o.
} 
Report of the Commission of Experts on the Former Yugoslavia stated that it was led to consider the idea of the establishment of an ad hoc international tribunal. According to the Commission:

States may choose to combine their jurisdictions under the universality principle and vest this combined jurisdiction in an international tribunal. The Nuremberg International Military Tribunal may be said to have derived its jurisdiction from such a combination of the national jurisdiction of the states parties to the London Agreement setting up that Tribunal. ${ }^{94}$

Not only did this legal opinion rejuvenate the disagreement over the jurisdictional basis of the Nuremberg Tribunal, it also cast doubt on the procedure by which an international criminal jurisdiction was to be established. ${ }^{95}$

On 25 May 1993, following the Commission's recommendation, the SC adopted, under Chapter vII of the UN Charter, Resolution 827 which established the International Criminal Tribunal for the Former Yugoslavia (ICTY). ${ }^{96}$ Similarly, on 8 November 1994 the SC adopted, again under Chapter VII of the UN Charter, Resolution 955, which established the International Criminal Tribunal for Rwanda (ICTR). ${ }^{97}$

The basis of the ad hoc tribunals' jurisdiction was territoriality in the case of the ICTY ${ }^{98}$ and territoriality and nationality in the case of the ICTR. ${ }^{99}$ Hence, it could be maintained that the ad hoc tribunals' adjudicative jurisdiction derived from a delegation of these jurisdictional bases. ${ }^{100}$ This view is supported by the assumption that the SC, when adopting a resolution establishing an

94 Interim Report of the Independent Commission of Experts Established Pursuant to Security Council Resolution 780 (1992), UN Doc. S/25274 (1993), par. 73.

95 See e.g. Scharf, "Nationals of Non-Party States,"; Morris, "High Crimes,".

96 Security Council Resolution 827 (1993) of 25 May 1993, adopting the Statute of the International Tribunal for the Prosecution of Persons Responsible for Serious Violations of International Humanitarian Law Committed in the Territory of the Former Yugoslavia since 1991, UN Doc. S/RES/827 (hereinafter ICTY Statute).

97 Security Council Resolution 955 (1994) of 8 November 1994, with annex containing the Statute of the International Criminal Tribunal for the Prosecution of Persons Responsible for Genocide and Other Serious Violations of International Humanitarian Law Committed in the Territory of Rwanda and Rwandan Citizens Responsible for Genocide and Other Such Violations Committed in the Territory of Neighbouring States between 1 January 1994 and 31 December 1994., UN Doc. S/RES/955 (hereinafter ICTR Statute).

98 ICTY Statute, Art. 1.

99 ICTR Statute, Art. 1.

100 See Akande, "Nationals of Non-Parties," 628; Dinstein, "The Universality Principle," 17-37. Scharf, "Nationals of Non-Party States," 108. 
international criminal tribunal under Chapter VII, exercises powers delegated to it by all the Member States of the UN. ${ }^{101}$ However, scholars are divided on which basis of jurisdiction exactly had been delegated. While Scharf argues that the delegated jurisdictional basis was universal jurisdiction, ${ }^{102}$ Akande claims it was territorial jurisdiction. ${ }^{103}$ Conversely, Morris 104 and former US Ambassador Scheffer ${ }^{105}$ contest that the SC was delegating any 'bases' of State jurisdiction to the ad hoc tribunals. In their opinion, the ad hoc tribunals' jurisdiction found its source exclusively in the power of the SC to maintain international peace and security. ${ }^{106}$

In Milutinovic et al., the defendants, who were accused of crimes committed in Kosovo, challenged the ICTY's jurisdiction on the ground that the Federal Republic of Yugoslavia (FRY) was not a UN Member State when the alleged crimes were committed. ${ }^{107}$ According to the defendants, the ICTY, a court created by the SC, could not have jurisdiction over crimes committed in a nonUN Member State. A potential solution to this challenge was to assert that the ICTY was exercising universal jurisdiction so that it would not be restricted to the territorial space of UN Members. However, the Trial Chamber eschewed the issue by stating that the FRY retained sufficient indicia of UN membership during that period to be amenable to the regime of the SC resolutions adopted for the maintenance of international peace and security. ${ }^{108}$ There was hence no need for the Trial Chamber to address the second strand of the motion which challenged the ICTY's universal jurisdiction. ${ }^{109}$

101 UN Charter, Art. 24 (1); Scharf, "Nationals of Non-Party States," 108-110; Akande, "Nationals of Non-Parties," 628; See Tadic Interlocutory Appeal Decision, Judge Sidhwa Separate Opinion, par. 85 .

102 Scharf, "Nationals of Non-Party States," 108-110.

103 Akande, "Nationals of Non-Parties," 628.

104 Morris, "High Crimes," 13.

105 Scheffer, "The Challenge," 68.

106 Morris, "High Crimes," 13; see Tadic Interlocutory Appeal Decision, par. 38.

107 Prosecutor v. Milutinovic et al., Case No. IT-99-37-PT, Motion Challenging Jurisdiction (May 6, 2003); see Akande, "Nationals of Non-Parties," p. 629-631. The ICTY Statute could apply to States which are not member of the UN by virtue of Article 2 (6) of the UN Charter. The ICJ in its advisory opinion in the Namibia Case declared that the non-Member States of the UN must "act in accordance with" the decisions of the UN, Legal Consequences for States of the Continued Presence of South Africa in Namibia (South West Africa) Notwithstanding Security Council Resolution 276, 1971 (Advisory Opinion), 1960 ICJ Report 16.

108 Prosecutor v. Milutinovic et al., Case No. IT-99-37-PT, Motion Challenging Jurisdiction (May 6, 2003), par. 44.

109 Ibid., par. 64. 
Judge Robinson, however, addressed this question in his separate opinion. According to Robinson:

It seems that when it is said that the ICTY is an example of universal jurisdiction, what is meant is that since the crimes in respect of which it has jurisdiction attract universal jurisdiction, the Security Council relied on such jurisdiction in establishing the Tribunal. It may be that this is said on the basis of a comparison with the manner in which the Allies combined the universal jurisdiction each of them had over the specified crimes to establish the Nuremberg Tribunal. But the comparison between the establishment of a criminal tribunal by States on the one hand, and the Security Council on the other, is not apt, because in respect of the latter, the source of the Council's power is its right under Chapter VII of the United Nations Charter to adopt measures for the maintenance of international peace and security. ${ }^{110}$

Robinson agreed that the ICTY is adjudicating crimes subject to universal jurisdiction, but that is not the basis under which the Tribunal was acting. In other words, Judge Robinson agrees with Morris and Scheffer; the jurisdiction of the ad hoc tribunals was based on the powers of the SC under Chapter VII tout court. The ICTY Appeals Chamber in Tadic Interlocutory Appeal on Jurisdiction made clear that the establishment of an international criminal tribunal is consistent with the SC's primary responsibility for the maintenance of international peace and security. ${ }^{111}$ But, beside Judge Robinson's separate opinion, the ad hoc tribunals have not clearly tackled their jurisdictional basis.

Following the establishment of the ad hoc tribunals, the idea of a permanent international criminal court began to gain popularity among the international community. Due to a "tribunal fatigue" at the SC, ${ }^{112}$ a permanent court established by treaty was needed with possibility for universal application.

Between the 15th June and 17th July 1998, the UN Diplomatic Conference of Plenipotentiaries on the Establishment of an International Criminal Court

\footnotetext{
110 Ibid., Separate Opinion of Judge Patrick Robinson, par. 46.

111 Tadic Interlocutory Appeal Decision, par. 32-40, see also Prosecutor v. Kanyabashi, Case No. ICTR-96-15-T, Decision on the Defence Motion on Jurisdiction (June 18, 1997).

112 Scharf, "The Politics of Establishing," 169; Scheffer, All the Missing Souls, 168.
} 
(Rome Conference) took place. As the Chairman of the Rome Conference Philippe Kirsch - reported, the negotiations regarding the adoption of the Statute of the International Criminal Court were tense and difficult but culminated effectively after five weeks with a vote of 120 to 7 , with 21 abstentions. ${ }^{113}$

The most controversial issue at the negotiation of the Rome Statute was the jurisdiction of the Court. The "question of questions of the entire project" was whether the Court would exercise universal jurisdiction or would need the consent of every State concerned with the crime. ${ }^{114}$ Like Hans-Peter Kaul pointed out, the conflicting principles were universality versus State sovereignty. ${ }^{115}$ Article 12, which provides for the preconditions for the exercise of jurisdiction, was until the last minute before the adoption of the Statute "a make or break provision".116 It was also felt essential that the SC be empowered to refer situations to the future permanent international criminal court. ${ }^{117} \mathrm{Oth}-$ erwise, the SC would be forced to continue establishing a succession of ad hoc tribunals in order to discharge its mandate, where the court would not have jurisdiction. ${ }^{118}$ Many consider, however, that because of the nature of the subject matter jurisdiction of the ICC, it could have exercised jurisdiction anywhere in the world without the consent of the territorial State, the national State or the referral of the SC under Chapter VII of the UN Charter. ${ }^{119}$

Indeed, the representatives of Germany made a proposal, which was supported by an important number of NGOs and States, ${ }^{120}$ that the Court would have inherent jurisdiction wherever a crime within its subject-matter jurisdiction had been committed. In other words, the Court would have had universal jurisdiction over aggression, genocide, crimes against humanity and war crimes, i.e. no nexus with a State party and the crimes would have been needed for the ICC to have competence over a case. However, this competence would

\footnotetext{
113 Kirsch and Holmes, "The Negotiating Process," 2-12.

114 Kaul and Chatidou, "Reflections on the ICC," 981.

115 Kaul, "Preconditions," 584.

116 Williams and Schabas, "Article 12," 547.

117 Yee, "Article 13 (b) and 16," 146.

118 Bassiouni, The Legislative History, 182, par. 84.

119 Kaul, "Preconditions," 584.

120 Schabas lists all the following as examples of States supporting Germany's proposal: UN Doc. A/CONF.183/SR.2, par. 54 (Sweden); UN Doc. A/CONF.183/SR.3, par. 21 (Czech Republic); par. 42 (Latvia); par. 76 (Costa Rica); UN Doc. A/CONF.183/SR.4/, par. 12 (Albania); par. 38 (Ghana); par. 57 (Namibia); UN Doc. A/CONF.183/SR.5 (Italy); par. 21 (Hungary); par. 32 (Azerbaijan); UN Doc. A/CONF.183/SR.6, par. 4 (Belgium); par. 16 (Ireland); par. 51-52 (Netherlands); par. 69 (Luxembourg); UN Doc. A/CONF.183/SR.8, par. 18; (Bosnia and Herzegovina); par. 62 (Ecuador). To read Germany's defence of its proposal see UN DOC. A/ CONF.183/SR.4, par. 20-21; Schabas, Commentary on the Rome Statute, 28o, fn. 16.
} 
still have been restricted by the principle of complementarity. That is, if a national system was able and willing to carry out the investigation or prosecution, the national system would keep its primary jurisdiction over the crime. ${ }^{121}$ Furthermore, even though the court's inherent jurisdiction over any crime within its subject-matter could have been exercised without the need to establish a link between the crime and a State party, States not party to the Statute were under no obligation to cooperate with the Court. ${ }^{122}$

At the other end of the spectrum, some delegations proposed that the mandatory consent of all of the interested States be required in order for proceedings to be initiated by the Court. South Korea made a proposal that it thought to be a "compromise formula" whereby the court would have jurisdiction if either the State that had territorial, active nationality, passive personality, or custodial jurisdiction was party to the Court. ${ }^{123}$ If one of those States was a State party, the nexus with the Court would become sufficient for the latter to seize jurisdiction. By including the custodial State as one of the States that would link the Court to the crimes, the Korean proposal equated in essence to conditional universal jurisdiction. ${ }^{124}$ Despite the fact that the Korean proposal was supported by $79 \%$ of the States present, ${ }^{125}$ an opposition led by the United States resisted this proposal, describing it indeed as 'universal jurisdiction'.

The United Kingdom paved the way for the Statute as it currently stands by proposing that the Court have jurisdiction only if both the custodial State and territorial State were States parties. The United Kingdom then amended its proposal to delete custodial State consent so that only territoriality was required. ${ }^{126}$ On the other hand, the US required that active nationality be required. ${ }^{127}$ The United States proposal was that the Court could only exercise jurisdiction over a case if (1) either the State of nationality of the suspect was a party to the Statute or (2) the jurisdiction of the Court had been triggered by the Security Council. Ultimately, the "final compromise" was that the ICC

\footnotetext{
121 See Rome Statute, Art. 17..

122 Article 9 (2) of the German proposal provided the possibility for the non-party States to accept to cooperate on an ad hoc basis with the Court.

123 Republic of Korea: proposal regarding Articles 6[9], 7[6], UN Doc. A/CONF.183/C.1/L.6, par. 4 .

124 See Cassese, "When May Senior State Officials Be Tried," 855-858; As Cassese defines it a conditional universal jurisdiction is contingent upon the present of the suspect in the forum State.

125 Kaul, "Preconditions," 6 oo.

126 Proposal by the United Kingdom of Great Britain and Northern Ireland, Trigger mechanism, UN Doc. A/AC.249/1998/WG.3/DP.1.

127 Proposal submitted by the United States of America, UN Doc. A/CONF.183/C.1/L.7o.
} 
would have inherent jurisdiction only in situations where crimes were committed by a national of a State party or in the territory of a State party.

The SC referral of a situation under Chapter VII of the UN Charter as provided for in Article 13 (b) of the Rome Statute was in the view of the United States the only way "to impose the court's jurisdiction on a non-party State". ${ }^{128}$ Conversely, some States were of the opinion that the General Assembly was the appropriate organ to refer situations or even that the SC could refer cases under Chapter VI of the UN Charter. ${ }^{129}$ The issue of the SC triggering a situation remained until the end of the Rome Conference "a controversy with a small but vocal minority opposing any role for it." 130 Despite this opposition there was broad support for providing a role for the SC to play within the triggering mechanism of the Court. ${ }^{131}$ Eventually, the SC was provided with the possibility to refer as well as defer situations before the Court. ${ }^{132}$

There appears to be four main views with regard to the jurisdictional basis of the ICC when it acts under an Article 13 (b) referral. First, territorial and active nationality jurisdictions are delegated to the ICC by the SC acting under Chapter VII. ${ }^{133}$ Due to the obligation States have under the UN Charter, they have to accept and carry out the referral and thus delegate their jurisdictions to the ICC. Second, the States that created the ICC and the others that have acceded to it have delegated their universal jurisdiction to the Court; ${ }^{134}$ even if during the negotiation in Rome, it was decided to limit this delegated universal jurisdiction to situations where the SC would consent. Third, due to the nature of the crimes within the ICC subject-matter jurisdiction the ICC is endowed with universal jurisdiction; 135 even if it was accepted in Rome to only exercise

128 Ambassador Scheffer, Head of the United States Delegation in Rome, before the United States Senate Foreign Relations Committee, 23 July 1998.

129 See Yee, "Article 13 (b) and 16," 149; see also Article 10 (3), Prep Com Draft Statute; ILC, and Add.1, Eighth report on the draft Code of Crimes Against the Peace and Security of Mankind by Mr. Doudou Thiam, Special Rapporteur, UN Doc. A/CN.4/43o, par. 89; ILC, Draft Statute for an International Criminal Court, with commentaries, UN Doc. A/49/10, par. $65^{-66 .}$

130 Williams and Schabas "Article 12," 549; See Report of the Ad hoc Committee on the Establishment of an International Criminal Court, 6 September 1995, UN Doc. A/5o/22, par. 121; see also Report of the Preparatory Committee, par. 13o. 132 (1996) UN Doc. A/Conf/183/2, Add. 1 and Add. 2.

131 Yee, "Article 13 (b) and 16," 149.

132 Rome Statute, Article 13 (b), 16.

133 E.g. Akande, "Nationals of Non-Parties," 628.

134 E.g. Scharf, "Nationals of Non-Party States," 108.

135 E.g. Kress, "Immunities under International Law," 246-250; Sadat, Transformation of International Law, 108-110; Ambos, "Punishment without a Sovereign?," 1-23. 
this universal jurisdiction where the SC would consent. ${ }^{136}$ Fourthly, and finally, the SC's power under Chapter VII forms the ICC's jurisdictional foundation over non-party States. ${ }^{137}$

The first and second views have already been addressed in the previous section. The first view was expressed by Akande's proposition about the delegation of jurisdiction concerning the ad hoc tribunals and the second view by Scharf's proposition of delegation of universal jurisdiction. The third and fourth views are actually extensions of the delegation theories. However, instead of being delegations from States they are delegations from the international community. The next section will develop this idea of a 'delegation from the international community' and, more specifically, will focus on what is referred to as the two 'conceptions' of an Article 13 (b) referral.

To come back to the 'concept-conception' distinction, the 'trunk' of this book's 'conceptual tree' is the ICC's exercise of prescriptive and adjudicative jurisdiction over the territory and nationals of a State neither party to the Statute nor consenting to ICC jurisdiction. This abstract idea provides the 'concept' of Article 13 (b) referrals to the ICC. The competing propositions about the jurisdictional basis of the ICC's exercise of jurisdiction without the consent of the territorial and the national State are 'conceptions' of Article 13 (b) referrals. The two 'conceptions' that are retained of this 'concept' are (1) universal jurisdiction arising from the nature of the crimes and (2) jurisdiction based on the powers of the SC under Chapter VII. These two 'conceptions' are obviously more controversial than the 'concept' as such, but that is exactly the purpose of using the 'concept-conception' distinction. ${ }^{138}$

The 'universal jurisdiction conceptions' and the 'Chapter VII conception' find their origin in international criminal law stricto sensu and UN law, respectively. More specifically, the first criminal jurisdiction finds its origin in the jus puniendi of the international community and the second in the SC's power to maintain international peace and security. In the next section, these two 'conceptions' are schematically outlined; a more in-depth analysis of their functioning, weaknesses and interactions with other norms of international law will be conducted in the subsequent chapters.

136 Gaeta and Labuda, "Trying Sitting Heads of State," 153-154.

137 Morris, “High Crimes,"; Williams, Jurisdictional Issues, 316-317.

138 Guest, Dworkin, 74. 


\subsection{Universal Jurisdiction Conception}

The theoretical foundations of the 'universal jurisdiction conception' reside in the jus cogens status of the crimes, their erga omnes character, and the jus puniendi of the international community. According to this 'conception', universal jurisdiction over aggression, genocide, crimes against humanity and war crimes arises from the nature of these crimes ${ }^{139}$ and from the obligation to exercise criminal jurisdiction when such egregious conduct occur. ${ }^{140}$ The obligation to punish perpetrators of international crimes forms the punitive power (jus puniendi) of the international community. ${ }^{141}$ The notion that individual criminal responsibility is established directly under international law for crimes of an international character brings forward the notion of international criminal law stricto sensu: ${ }^{142}$ There is no need for a State to prescribe the criminality of the act since it is international law that asserts individual criminal responsibility. ${ }^{143}$ Ultimately, international criminal law stricto sensu is based on the idea of a jus puniendi of the international community to punish perpetrators of crimes under international law that shock the conscience of mankind. ${ }^{144}$

Bassiouni states that if a given crime "threaten[s] the peace and security of humankind" and "shock[s] the conscience of humanity" its prohibition is "part of jus cogens."145 Many commentators believe that the prohibitions of aggression, genocide, crimes against humanity and war crimes are jus cogens. ${ }^{146}$

139 Luban, "Fairness to Rightness,".

140 See e.g. Geneva Convention I, Art. 49-50; Geneva Convention II, Art. 50-51; Geneva Convention III, Art. 129-130; Geneva Convention IV, Art. 146-147; Additional Protocol, art. 85, 86, 88; Convention Against Torture and Other Cruel, Inhuman or Degrading Treatment or Punishment (Dec. 10,1984), 85 UNTS 1564, Art. 6 (hereinafter Convention against Torture); International Convention for the Protection of All Persons from Enforced Disappearances (Jan. 12, 2007) General Assembly Resolution 61/177, Annex, 11, UN Doc. A/RES/61/77, Art. 9 (hereinafter Convention on Enforced Disappearances); ILC, Draft Code of Crimes Against Peace and Security of Mankind, Art. 18-19; furthermore, the preamble of the Rome Statute "recalls the duty of every State to exercise its criminal jurisdiction over those responsible for international crimes"; Kress, "Immunities under International Law," 246-250; See Ambos, "Punishment without a Sovereign?,"; such obligation does not apply to the crime of aggression, see for instance Res. RC/Res.6, Annex III (June 11, 2010), par. 5.

141 Ambos, International Criminal Law, 58-6o.

142 Schwarzenberger, "The Problem of an International Criminal Law," 264-74 (1950); Kress, "International Criminal Law", par. 10-14.

143 Nuremberg Principles No. 1 and 2.

144 Kress, "Immunities under International Law," 246; see Ambos, "Punishment without a Sovereign?," $1-23$.

145 Bassiouni, "Jus Cogens and Obligatio Erga Omnes," 69.

146 Ibid., at 68; Prosecutor v. Furundzija, Case No. IT-95-17/1-T, Judgment (Dec. 10, 1998), par. 153-157; Prosecutor v. Delalic et al., Case No. IT-96-21-T, Judgment (Nov. 16, 1998), par. 453; 
Jus cogens norms are characterized as "superior legal norms". ${ }^{147}$ These superior legal norms are norms accepted and recognized by the international community of States as a whole as norms from which no derogation are permitted..$^{148}$ Thus, no State can derogate from the prohibition of aggression, genocide, crimes against humanity and war crimes. ${ }^{149}$ Jus cogens crimes, Orakhelashvili has stated, "entail objective illegality whose redress is a matter of community interest despite the attitudes of or prejudices to individual states". 150 "Universal jurisdiction", he adds, "enables States to prosecute jus cogens crimes in the community interest". 151

Most of the crimes that are jus cogens entail a duty to prosecute or extradite, or the so-called aut dedere aut judicare principle. ${ }^{152}$ The aut dedere aut judicare principle reinforces the idea of an obligation (or a right) of the international community to assert jurisdiction over the crimes giving rise to this norm. ${ }^{153}$ The International Court of Justice (ICJ) in the Barcelona Traction Case stated that there are "obligations erga omnes" which by their very nature are the concern of all States. The ICJ clarified that "[i]n view of the importance of the rights involved, all States can be held to have a legal interest in their protection". ${ }^{154}$ Bassiouni maintains that the jus cogens and erga omnes nature of international crimes obliges the international community to prosecute them. ${ }^{155}$ Kress suggests that Article 48(1) (b) of the ILC's Article on the Responsibility of States for Internationally Wrongful Acts ${ }^{156}$ confirms that any State may act against a breach of an obligation owed to the international community as a whole. ${ }^{157}$ Hence it is argued that any State

Prosecutor v. Kupreskic et al., Case No. IT-95-16-T (Jan. 14 200o), par. 520; ILC, Draft Articles on Responsibility of States for Internationally Wrongful Acts, with commentaries UN Doc. A/56/10 (2001), at 112; Einarsen, The Concept of Universal Crimes, 62.

147 Einarsen, The Concept of Universal Crimes, 62.

148 Vienna Convention on the Law of Treaties (May, 23 1969) 1155 UNTS 331, Art. 53 (hereinafterVCLT).

149 Torture may also be added to this list.

150 Orakhelashvili, Peremptory Norms, 288.

151 Ibid.

$15^{2}$ Bassiouni, "Jus Cogens and Obligatio Erga Omnes,".

153 Bassiouni, "Jus Cogens and Obligatio Erga Omnes,".

154 Barcelona Traction, Light and Power Co. Ltd. (Belgium v. Spain), 1970 ICJ Reports 32, par. 32-33; East Timor Case (Portugal v. Australia), 1995 ICJ Reports 9o; Legal Consequences of the Construction of a Wall in the Occupied Palestinian Territory (Advisory Opinion) 2004 ICJ Rep. 136.

155 Bassiouni, "Jus Cogens and Obligatio Erga Omnes,".

156 ILC, Draft Article on the Responsibility of States for Internationally Wrongful Acts, Art. 48.

157 Kress and Prost, "Article 98," 1612; Kress, "Immunities under International Law," 248. 
may assert jurisdiction over a breach of an obligation owed to the international community as a whole.

More importantly, the international community itself may assert that authority. ${ }^{158}$ Because of the fundamental values at stake, "the international community [...] may prescribe international rules of conduct, adjudicate breaches of those rules, and enforce those adjudications." ${ }^{159}$ Thus, the international community would work side by side with national jurisdictions in order to investigate and prosecute crimes that concern the international community as a whole. ${ }^{160}$ Jurisdiction over crimes of such a nature would float to any entity ready to assert authority over perpetrators of crimes of such an international character. ${ }^{161}$ The 'universal jurisdiction conception' conjures the idea of "floating" universal jurisdiction. ${ }^{162}$ Indeed, the jus puniendi of the international community can be exercised by States or through other organs as designed by the international community. ${ }^{163}$ This jus puniendi if exercised by organs of the international community gives them wider power than "a national criminal court, which acts as a mere fiduciary of the common good."164

The ICC pertains to assume that role of exercising the jus puniendi of the international community. A significant majority of States were invited by the United Nations at the Rome Conference to draft the founding instrument of this organ of the international community. During a notable part of the negotiation of the Rome Statute efforts were made to reach decisions by consensus. ${ }^{165}$ The consensus could not be maintained 166 but an overwhelming majority of the States approved the text of the Rome Statute. ${ }^{167}$ Proponents of the 'universal

158 Kress and Prost, "Article 98," 1612; Sadat, Transformation of International Law, 107-111; Triffterer, "Preliminary Remarks," 25; Bassiouni, "The Sources and Content," 4-17.

159 Sadat, Transformation of International Law, 108.

16o Olasolo, The Triggering Procedure, 14.

161 Ibid., p. 14.

162 See Williams, Jurisdictional Issues, 314-316; discusses Prosecutor v. Kallon and Kamara, Case No. SCSL-2004-15-AR72(E), Decision on Challenge to Jurisdiction: Lomé Accord Amnesty (March 13, 2004), par. 88 and Prosecutor v Gbao, SCSL-2004-15-PT, Decision on the Invalidity of the Agreement Between the United Nations the Government of Sierra Leone on the Establishment of the Special Court (May 15, 2004), par. 8; which appear to refer to the existence of floating universal jurisdiction.

163 Olasolo, The Triggering Procedure, 15; Bassiouni, A Draft International Criminal Code, 107 et ss..

164 Kress, "Immunities under International Law," 246.

165 Olasolo, The Triggering Procedure, 17.

166 Seven States voted against the adoption of the Rome Statute.

167 The Rome Statute has been adopted by 120 States, signed by 139 States and at the time of writing ratified by 123 States. 
jurisdiction conception' argue that the Rome Statute is a legislative act of the international community, which defines the crimes it considers "the most serious crimes of concern to the international community as a whole". 168 Leyla Sadat affirms that in Rome the "universality principle has been extended from a principle governing inter-State relations to one of general prescriptive international law."169 Thus, individuals from all over the world are subject to the jus puniendi of the international community incarnated by the ICC. The jurisdictional power of the ICC does indeed have universal reach when the SC gives the laissez-passer to the ICC to act outside of its States parties' territories and nationals. ${ }^{170}$ As mentioned above, according to the 'universal jurisdiction conception' of Article 13 (b), the ICC is endowed with universal jurisdiction arising from the nature of the crimes within its subject-natter jurisdiction, that it will exercise where the SC would consent - not the other way around.

All these elements - jus puniendi of the international community, jus cogens, and erga omnes norms - are latent in the 'concept' of the exercise of jurisdiction without the consent of neither the territorial State nor the national State. These norms form the legal regime underlying the 'universal jurisdiction conception'. Accordingly, when ICC jurisdiction is triggered under Article 13 (b) this entire regime is brought into action. As emphasized by the fourth paragraph of the preamble of the Rome Statute, the telos of the 'universal jurisdiction conception' is to ensure that the most serious crimes of concern to the international community as a whole do not go unpunished. The 'universal jurisdiction conception' has to be primarily understood in light of this purpose.

\subsection{Chapter VII Conception}

The second 'conception' of the referrals under Article 13 (b) Rome Statute is jurisdiction based on the powers of the SC under Chapter VII of the UN Charter. This 'conception' conceives that the jurisdiction over the territory and nationals of a State neither party to the Rome Statute nor consenting to the ICC exercise of jurisdiction is strictly based on the Chapter viI powers of the SC.

States have vested, qua the UN Charter, the SC with the competence to invoke extraordinary powers that might be necessary to restore or maintain international peace and security. ${ }^{171}$ These extraordinary powers are the so-called Chapter VII powers. Once the SC has established the existence of a threat to international peace and security under Article 39 of the UN Charter, it can

\footnotetext{
168 Sadat and Carden, “An Uneasy Revolution," 412.

169 Ibid., at 412.

170 Olasolo, The Triggering Procedure, 17.

171 UN Charter, Art. 24(1).
} 
trigger its Chapter VII powers. While the establishment of criminal tribunals is not included in the list of measures open to the SC under Article 41, it has been recognized that this list is not exhaustive. ${ }^{172}$ The SC is a political organ which cannot exercise judicial powers. However, in order to assume its primary responsibility, it enjoys wide discretionary powers. ${ }^{173}$ Thus, as instruments for the exercise of its principal function of maintenance of peace and security, the SC can establish subsidiary organs, such as the ICTY and ICTR, ${ }^{174}$ which will exercise judicial functions. ${ }^{175}$ The ICC is not a subsidiary organ of the SC but a referral under Article 13 (b) can be conceived as an enforcement measure of the SC. 176

Article 13 (b) of the Rome Statute provides that the referral needs to be "by the Security Council acting under Chapter vir of the Charter of the United Nations." A referral not based on a Chapter VII resolution will not confer jurisdiction on the Court unless it concerns a crime committed by a national or on the territory of State party to the Rome Statute or that has issued a declaration of acceptance. ${ }^{177}$ Since a SC referral to the ICC is made under Chapter vII of the UN Charter, Members of the UN are obliged, pursuant to Article 25 of the Charter, to accept and carry out the decision of the SC to refer the situation to the ICC.

The SC is not restrained by the jurisdictional bases relied upon by States to justify their exercise of jurisdiction. ${ }^{178}$ Indeed, when a criminal jurisdiction is based on the Chapter VII power of the SC, classical theories of international law on jurisdictional basis are of no avail. ${ }^{179}$ Criminal jurisdiction springing out from a Chapter viI resolution does not have to rest on the territoriality, nationality or universality principle. Rather, it is the powers of the SC to take

\footnotetext{
172 Tadic Interlocutory Appeal Decision, par. 33-36.

173 Ibid.

174 According to the Appeals Chamber of the Special Tribunal for Lebanon (STL), the STL as well was established by the SC, Prosecutor v. Ayyash et al., Case No. STL-11-01,Decision on the Defence Appeals Against the Trial Chamber's "Decision on the Defence Challenges to the Jurisdiction and Legality of the Tribunal", Separate and Partially Dissenting opinion of Judge Baragwanath and Judge Riachy, Special Tribunal for Lebanon (Oct. 24, 2012); Furthermore, the Special Court for Sierra Leone considered it had a Chapter vil status in Prosecutor v. Taylor, SCSL-2003-01-I, Decision on Immunity from Jurisdiction, Special Court for Sierra Leone (May 31, 2004) (hereinafter after Decision on Taylor Immunity).

175 Tadic Interlocutory Appeal Decision, par. 37-38.

176 See Chapter 2, section 1.1 for a further analysis of this aspect.

177 Rome Statute, Art. 12.

178 Williams, Jurisdictional Issues, 316-317.

179 Ibid., at 317 .
} 
steps necessary to restore or maintain international peace and security that are the sources from which the judicial body's jurisdiction stems. ${ }^{180}$

Predicating the exercise of jurisdiction upon the SC's power has great normative weight. According to Sarooshi, what the UN Member States have delegated to the SC through the mechanism of the UN Charter "was not sovereignty per se but an international police power of States". ${ }^{181}$ In the name of this "international police power" the SC possesses a competence that is greater than that possessed by an individual State. Indeed, "when the international community acts then it can confer powers on an international organization which sovereign States acting individually could not". ${ }^{182}$ Moreover, in accordance with Article 103 of the Charter, the obligations of UN Members in fulfillment of SC resolution under Chapter viI prevail over their obligations under any other international agreement. ${ }^{183}$

However, the link between international peace and security and international criminal justice is a vexed one. The Preamble of the Rome Statute asserts that the crimes within the subject-matter jurisdiction of the ICC "threaten the peace, security and well-being of the world." 184 Nevertheless, acts of genocide, crimes against humanity and war crimes do not necessarily constitute threats to international peace and security. ${ }^{185}$ In fact, it may be asked whether international justice really constitutes a suitable means for achieving international peace. ${ }^{186}$ Article 16 of the Rome Statute shows the flipside of the SC role within the international criminal justice system. According to this provision, the ICC may not commence or proceed with an investigation or prosecution for a period of 12 months after the SC, in a resolution adopted under Chapter VII of the UN Charter, has requested the Court to that effect. Thus, it is acknowledged that the maintenance or restoration of international peace and security may sometimes require that the process of international criminal justice be suspended.

\footnotetext{
180 See Morris, "High Crimes," 36. Williams, Jurisdictional Issues, 317.

181 Sarooshi, Collective Security, 28.

182 Ibid., p. 29.

183 Questions of Interpretation and Application of the 1971 Montreal Convention arising from the Aerial Incident at Lockerbie (Libyan Arab Jamahiriya v. United States of America), Order of 14 April 1992 Request for the indication of Provisional Measures, 1992 ICJ Rep 126-127; Report of the Study Group of the ILC on Fragmentation of International Law, at 166-18o.

184 Rome Statute, preamb. par. 4.

185 Condorelli and Villalpando, "Referral and Deferral," 630-633; see however, General Assembly, Resolution 6o/1, 2005 World Summit Outcome (Oct. 24, 2005), UN Doc. A/RES/ 6o/1, par. 138-139.

186 Condorelli and Villalpando, "Referral and Deferral," 632.
} 
The primary concern of the SC is not the upholding of justice and international law but the maintenance of international peace and security. ${ }^{187}$ The omissions of the terms "justice and international law" in the first part of Article 1 (1) of the UN Charter means that, when adopting enforcement measures, the SC can deviate from these when acting in the interest of peace and security. ${ }^{188}$ However, as the ICTY Appeals Chamber in the Tadic Interlocutory Appeal Decision eloquently put: the SC is not legibus solutus (unbound by law); it has to abide by its constituent instrument, the UN Charter. ${ }^{189}$

The "international police power", Article 25 and 103 of the UN Charter; the purposes and principles of the UN are part of the legal regime applicable when we consider the 'concept' of an Article 13 (b) referral under the 'Chapter VII conception'. Thus, when the ICC exercises jurisdiction without the consent of either the territorial State or the national State, this legal regime is brought into play. The telos of the 'Chapter VII conception' is obviously the maintenance of international peace and security. Hence, the 'Chapter viI conception' of an ICC exercise of jurisdiction without the consent of the territorial and national State should be viewed through the lens of this telos.

\section{The Amendments to the Rome Statute}

The Rome Conference had ended with the understanding that the Rome Statute was still incomplete. While aggression was listed in Article 5 as one of the crimes within the Court's jurisdiction, such jurisdiction could not be exercised until a definition was adopted. ${ }^{190}$ Furthermore, some States believed that the Court should also have had jurisdiction over crimes such as terrorism, drug trafficking and the use of weapons of mass destruction. ${ }^{191}$ Article 121 Rome Statute was thus included in the Statute in order to regulate future amendments.

187 See De Wet, Chapter VII Powers, 183-184; UN Charter, Art 1, 24.

188 De Wet, Chapter VII Powers, 186-187. Akande, "The International Court of Justice," 309343 .

189 Tadic Interlocutory Appeal Decision, par. 28.

190 Rome Statute, Art. 5(2).

191 The Final Act of the Rome Conference, adopted at the same time as the Statute, includes a resolution recommending that the Review Conference consider means to enable the inclusion of crimes of terrorism and drug crimes. Final Act of the United Nations Diplomatic Conference of Plenipotentiaries on the Establishment of an International Criminal Court, UN Doc. A/CONF.183/13. 
Amendments with respect to crimes listed in Articles 5, 6, 7 and 8 are subject to Article 121 (5) of the Rome Statute. The entry into force of such amendments takes place as soon as one State ratifies the amendment, but they enter into force only for those States party that have accepted the amendment. If a State Party does not accept an amendment relating to subject-matter jurisdiction, "the Court shall not exercise its jurisdiction" regarding this 'new' crime "when committed by that State Party's nationals or on its territory." Article 121(5) thus creates an exception to the jurisdictional scheme of Article 12, which provides the Court with personal and territorial jurisdiction over its States parties. It has been argued that the clear wording - "shall not exercising its jurisdiction [...] when committed by that State Party's nationals or on its territory" - entirely prohibits the Court from exercising its jurisdiction over a non-ratifying State party's nationals and territory. ${ }^{192}$ Given that Article 121 (5) does not distinguish between the trigger mechanisms, some authors claim that such ban strictly relating to States parties that have not ratified the amendment would also apply in referrals under Article 13 (b). ${ }^{193}$ On the other hand, according to Article 121 (5), new crimes apply, irrespective of the trigger mechanism, if: (i) committed by a national of an accepting State Party over the territory of a non-party State; as well as if (ii) committed by a national of a non-party State in the territory of an accepting State party. To put it simply, Article 121 (5) discriminates against non-party States. ${ }^{194}$

\subsection{The Kampala Review Conference}

The first Review Conference held in Kampala in 2010 was planned to address inter alia proposed amendments on a definition of the crime of aggression and adding certain prohibited weapons to the war crimes provisions. But most of the academic debate as well as that among States was focused on the aggression amendment.

As McDougall observed, "the most furious debates were not over the definition of the crime of aggression but rather over who would be subject to the ICC's jurisdiction". 195 Article 5(2) of the Rome Statute provided that "[t]he Court shall exercise jurisdiction over the crime of aggression once a provision is adopted in accordance with Articles 121 and 123 defining the crime and setting out the conditions under which the Court shall exercise jurisdiction with

\footnotetext{
192 Zimmermann and Şener, "Chemical Weapons," 444-45.

193 Ibid., at 444-45.

194 See Wegdwood, "An American Perspective," 104.

195 McDougall, The Crime of Aggression, 205.
} 
respect to this crime." The procedure to be applied for the 'adoption' of the amendments on aggression was indeed subject to several interpretations.

After several rounds of proposal on the Court's jurisdictional scheme to be adopted with regards to the crime of aggression, the 'Kampala Compromise' was reached. ${ }^{196}$ Article 8bis provides the definition of the crime of aggression, and Article 15bis and ter determine the conditions under which the ICC will exercise jurisdiction in respect of the crime of aggression, when triggered by a State referral and an investigation proprio motu or by a referral under Article 13 (b). ${ }^{197}$ The compromise, so to say, consisted in: on the one hand, excluding non-party States from the Court's jurisdiction, absent a SC referral, and, on the other hand, requiring States Parties to actively opt out if they want to avoid jurisdiction over their alleged acts of aggression. ${ }^{198}$ Nonetheless, the Kampala Compromise was quickly decried as not conforming with Article 121 (5) Rome Statute, in that the amendment would enter into force for all States parties, and the Court could exercise jurisdiction if the aggressor State had not opted out-two issues which will haunt ASP for the next 7 years. Conversely, the fact that Article 15bis (5) excluded the Court's jurisdiction over the territory and nationals of a State not party to the Rome Statute was not strongly objected.

Beside aggression, the States parties present at the Kampala Review Conference were also negotiating an amendment criminalizing-as part of Article 8 'War Crimes'-the use of poisoned weapons, asphyxiating gases, and expanding or flattening bullets in non-international armed conflicts. ${ }^{199}$ Though not insignificant-these proscriptions include "many and perhaps all uses of lethal chemical weapons", ${ }^{200}$ the war crimes amendment received little (if not at all) attention. The Working Group in charge of the war crimes amendment noted that the procedure for entry into force was related to the debate over the crime of aggression. ${ }^{201}$ However, the same type of compromise over the Court jurisdictional scheme as for the crime of aggression did not occur. On the one hand,

196 ICC, Assembly of States Parties, Review Conference, The Crime of Aggression, Resolution RC/Res.6, 11 June 2010 (hereinafter Resolution RC/Res.6).

197 Article 15 bis for State referrals and investigations proprio motu. And, Article 15ter for referrals under Article 13(b).

198 Barriga and Blokker, "State Referrals and Proprio Motu Investigations", 652-674.

199 International Criminal Court, Assembly of States Parties, Review Conference, Amendments to Article 8 of the Rome Statute, Res. RC/Res.5, 10 June 2010 (hereinafter Res. RC/ Res.5).

200 See Zimmermann and Şener, "Chemical Weapons," 441-442; Akande, "Use of Chemical Weapons," EJIL Talk! (Aug. 23, 2013), available at https://www.ejiltalk.org/can-the-iccprosecute-for-use-of-chemical-weapons-in-syria/.

201 Official Records of the Review Conference of the Rome Statute of the International Criminal Court, Kampala, 31 May-11 June 2010, 2010, ICC Doc. RC/11, 21 December 2010, p. 72. 
it was decided that the expanded war crimes provisions would only enter into force for States that have ratified it - no opt out is necessary for being excluded from the Court jurisdiction. And, on the other hand, the resolution to which the war crimes amendment is annexed states that the Review Conference "confirm [s] its understanding that in respect to this amendment the same principle that applies in respect of a State Party which has not accepted the amendment applies also in respect of States that are not parties to the Statute."202

The Kampala Review Conference approach to the war crimes amendment seems to set a pattern for the amendment to the crimes within the jurisdiction of the Court: any new amended crime would only be applicable to the territory and nationals of States that have consented.

\subsection{The New York Session}

The new pattern established with respect to the war crimes amendment will indeed follow on the activation of the Court's jurisdiction over the crime of aggression. The activation decision, which was postponed in Kampala to at least 1 January 2017, was placed on the agenda of the 16th session of the ASP held in December 2017 in New York. In Kampala, it had been agreed that the jurisdictional scheme of Article 12 would apply to the aggression amendment, unless the active nationality State had issued an opt-out declaration, or if either the active nationality State or the territorial State are not parties to the Rome Statute. The text of the amendments, encapsulated in Article 15bis (4) and (5), certainly provides for such jurisdictional scheme. ${ }^{203}$

Nonetheless, the New York session was taken as a further opportunity to revisit the conditions for the Court to exercise jurisdiction over the crime of aggression. This time, two States - namely, UK and France - were not ready to compromise. ${ }^{204}$ The two permanent members of the SC would only accept that like for the war crimes amendment, in case of a State referral or proprio motu investigation the Court would have jurisdiction, only if, the crime was committed in the territory of a State party that ratified the amendment, and by a national of a State party that ratified the amendment. Accordingly, the New York Resolution activating the Court's jurisdiction over the crime of aggression suggests that only the SC can trigger the Court's jurisdiction if either the aggressor State or the victim State have not ratified the Rome Statute and its amendment. ${ }^{205}$

\footnotetext{
202 Resolution RC/Res.5, par. 3.

203 Rome Statute, art. 15 bis (4) and (5). See Zimmermann, "A Victory," 20, 22.

204 See Kress, "On the Activation," 11-12.

205 Resolution on the Activation of the jurisdiction of the Court over the crime of aggression, 14 December 2017, ICC-ASP/16/Res.5, op. par. 2 (hereinafter ICC-ASP/16/Res.5).
} 
A further amendment was also adopted in New York, relating once again to the war crimes provision-this time prohibiting three kinds of weapons in both international and non-international armed conflict. ${ }^{206}$ Like its predecessor, the enabling resolution notes that the Court shall not exercise its jurisdiction regarding the crime covered by the amendment when committed by non-ratifying State party's nationals or on its territory, and confirms its understanding that the same exemption applies to non-party States. ${ }^{207}$

Despite the firm wording of the exemption paragraphs in the ASP's resolutions adopting the amendments, it remains unclear whether they will have their expected effects. ${ }^{208}$ While States may have expressed their preference for a new jurisdictional scheme, judges remain with the final say. ${ }^{209}$ This was certainly what the majority of States believed in New York when facing the UK and France' stumbling block. Indeed, the New York resolution on aggression contains a symbolic paragraph pointing out that ultimately it is the ICC Judges that will have to assess the weight of the resolution against the wording of the amended articles and the Rome Statute. ${ }^{210}$ Nonetheless, it is evident that all amendments to the Court's jurisdiction have been accompanied by a text emanating from the State parties 'confirming' their 'understanding' that nonconsenting States were exempted.

The resolutions accompanying the amendments to the Rome Statute undoubtedly challenge the foundation of the 'universal jurisdiction conception'and to a certain extent of the 'Chapter viI conception'. While the new crimes added to the Statute reveal the same nature as the crimes already within the Court's jurisdiction, the resolutions illustrate that such nature might not always justify a jurisdiction solely based on territoriality or active personality both jurisdictional basis appear to be required for the amended crimes.

Such fragmented regime does not however signify the end of the 'universal jurisdiction conception'. Indeed, the proponents of this conception of Article 13 (b) are still vocal. For example, as recently as 2017, Paola Gaeta and Patryk Labuda argued that "the ICc's jurisdiction exists independently of where or by whom crimes are committed and in this sense it is already 'universal."'11 Their understanding on whether the immunity of heads of States not party to

206 Resolution on amendments to article 8 of the Rome Statute of the International Criminal Court, Resolution ICC-ASP/16/Res.4, 14 December 2017.

207 Resolution ICC-ASP/16/Res.4, op. par. 2 (hereinafter ICC-ASP/16/Res.4).

208 Trahan, "From Kampala to New York," 197-243.

209 Zimmermann, "A Victory," 24-25.

210 ICC-ASP/16/Res.5, op. par. 3.

211 Gaeta and Labuda, "Trying Sitting Heads of State," 153. 
the Rome Statute is relevant before the ICC relies on the distinction between the universal jurisdiction basis of the Court and its exercise of jurisdiction when triggered by a referral under Article 13 (b). ${ }^{212}$ Not long ago, Carsten Stahn exposed the same universalist rationale to counter the argument that ICC's possible situations in Palestine and Afghanistan are limited by the nemo dat quod non habet doctrine. ${ }^{213}$ Despite the challenges the States parties posed to the 'universal jurisdiction conception' through the resolutions accompanying the amendments to the Rome Statute it is generally agreed that "States Parties entrusted the Court to have a final say over certain issues, including the question whether or not the Court is entitled to exercise jurisdiction."214 While this book shows that the 'universal jurisdiction conception' should be discarded for the 'Chapter vil conception', it also demonstrates that the Court has at times favored the former over the latter. It is thus unclear how (and if) the Court will interpret the jurisdictional scheme governing the amended crimes in strict observance of the law of treaties or will be driven by the raison d'être of the Court.

With the exception of the aggression amendments, the resolutions enabling the amended war crimes are also potentially undermining the reach of the Court's jurisdiction when triggered under Article 13 (b). Given that the war crimes amendments do not explicitly provide for SC referrals, as does Article $15 \operatorname{ter}(1)$ of the aggression amendments, it has been argued that they do not apply under this trigger mechanism. ${ }^{215}$ This argument is reinforced by the 'understanding' that the amendments will not apply to non-party States. Zimmerman suggests that negotiating States might have believed that the SC did not have the power to confer to the ICC jurisdiction over such newly added crimes. ${ }^{216}$

Conversely, and more persuasively, it can be argued that since a referral under Article 13 (b) entitles the Court to "exercise its jurisdiction with respect to a crime referred to in article 5", all crimes listed therein fall within the scope of a referral under Article 13(b). ${ }^{217}$ Accordingly, the amendment on aggression contains a specific article regulating the trigger mechanisms because it is subjected to different safeguards than other crimes. ${ }^{218}$ Given that the newly

\footnotetext{
212 Ibid., at 153-154.

213 Stahn, "A Reply to Michael Newton," 446-448.

214 Ibid., at 447.

215 Zimmermann and Şener, "Chemical Weapons," 443-47; contra see Reisinger Coracini, "Amended Most Serious Crimes," 707-708 (2008); Kress and Von Holtzendorff, "The Kampala Compromise," 1197 fn 65.

216 Zimmermann and Şener, "Chemical Weapons," 443-47

217 The current amendments to the war crimes provision are part of the crimes referred to in article 5, paragraph (1) (c).

218 In particular, for Security Council referrals, article 15 ter (2) and (3) regulate the time from which the Court can exercise jurisdiction in a different manner than 121 (5). The
} 
added war crimes provisions are not politically controversial as the crime of aggression, Article 13 (b) applies without prerequisites. With regards to the restrictions provided by Article 121 (5) and the enabling resolutions, Akande argues they solely apply to State referrals and proprio motu investigations. ${ }^{219}$ Referrals under Article 13 (b) instead are not based on State's consent. Indeed, as this book shows, Article 13 (b) referrals are either based on an already existing universal jurisdiction or on the conferral of jurisdiction by the SC using its Chapter VII powers.

Furthermore, the resolutions on war crimes contradict the Statute by providing that the Court shall not exercise its jurisdiction over a crime covered by the amendments if the conduct took place in the territory or was committed by a national of a non-party State. Given that only an amendment per se can modify the Statute and not their enabling resolutions, it can be claimed that the operative paragraphs conflicting with Article 12 and 121 (5) constitute illegitimate attempts to modify the Statute. Accordingly, only the changes brought through formal amendments, such as Article 15bis (4) and (5), would be binding on the Court. ${ }^{220}$

Even if one considers that the resolutions should be taken into account, as "subsequent agreement[s] between the parties regarding the interpretation of the treaty or the application of its provisions", ${ }^{221}$ they cannot amend the Rome Statute. ${ }^{222}$ A subsequent agreement can however be of assistance when interpreting the text of a provision subject to uncertainties. The resolution activating the crime of aggression might be of use in interpreting the ambiguity in the text of Article 15bis (4) - relating to the Court's jurisdiction over the crime of aggression in State referrals and proprio motu investigations. With respect to the war crimes amendments, their texts - which only speak of the crimes definition-are sufficiently clear for not requiring the judges to question whether the Statute's trigger mechanisms are subject to a different jurisdictional scheme. That being said, the resolutions might serve the judges to interpret whether a 'new' crime was considered reflective of customary international law at the time of their adoption. ${ }^{223}$ This will be crucial as we will

safeguards are however more developed with regards to State referrals and proprio motu investigations.

219 Akande, "Use of Chemical Weapons in Syria?," EJIL Talk! (Aug. 23, 2013), avaiblable at https://www.ejiltalk.org/can-the-icc-prosecute-for-use-of-chemical-weapons-in-syria/.

220 Trahan, "From Kampala to New York," 232-233.

221 VCLT, Article 31(3)(a).

222 Trahan, "From Kampala to New York," 232.

223 The Kampala Review Conference explicitly affirmed that the amendment on war crimes reflected customary international law. See Resolution RC/Res.5, par. 8-9; The other amendments were not accompanied by such affirmation. See Akande, "New War Crimes," 
see later when applying the principle of legality, and assessing whether the immunity of State officials is relevant in situations where the Court exercises jurisdiction over the nationals and territories of States not party to the Rome Statute nor consenting to its jurisdiction. It will also be determinant when scrutinizing whether each of our conception is able to ground its exercise of adjudicative and prescriptive jurisdiction without breaching the sovereign rights of the affected State(s).

\section{Conclusion}

The history of international criminal justice is full of uncertainties. One of the most ambivalent issue is the jurisdictional basis of international criminal tribunals and courts. By declaring that their Charter's drafters have done together what could have been done by any one of them singly, the IMT gave a great impulse to the principle of universal jurisdiction. Indeed, from Nuremberg to The Hague and Arusha, (international) criminal jurisdictions have been set up without the explicit consent of the States with primary territorial and national jurisdiction. However, to justify this exercise of jurisdiction power was always in the background: occupying power for the IMT and Chapter VII powers for the ad hoc tribunals. Hence, despite the words of the Commission of Experts on the Former Yugoslavia, a 'universal jurisdiction conception' of these tribunals is contested.

The establishment of a permanent international criminal court with an inherent universal jurisdiction came nail-bitingly close. But, ultimately, the Rome Statute's drafter opted for consensus and predicated the ICC's exercise of jurisdiction on State consent. That is, with the exception of Article 13 (b). Is Article 13 (b) predicated on the nature of the crimes within the Rome Statute - crimes which are essentially subject to universal jurisdiction, at least when exercised by States? Or, simply on the power of the SC to maintain international peace and security?

Article 13 (b) referrals make the universal applicability of the Rome Statute a reality. However, the complexity and the novelty of the Rome Statute make its universal reach problematic. The Rome Statute endows the Court with international legal personality and its own definition of crimes, list of defenses, modes of liability, relation with domestic jurisdiction (i.e., principle

EJIL Talk! (Jan. 2, 2018), available at https://www.ejiltalk.org/customary-internationallaw-and-the-addition-of-new-war-crimes-to-the-statute-of-the-icc/; See Kress and Von Holtzendorff, "The Kampala Compromise," 2118 (2010) with regards to aggression. 
of complementarity) and obligation of States. ${ }^{224}$ All these aspects spawn complex and divergent views when put into the context of a referral under Article 13 (b) of a situation with respect to a State that has not ratified the Statute. Obviously, the first issue at stake is the "bête-noire of the international criminal lawyer"; State sovereignty. ${ }^{225}$ Depending on the approach taken, 'universal jurisdiction conception' or 'Chapter VII conception', the exercise of jurisdiction by the ICC over a non-party State comes with different normative content and hierarchy. The universality doctrine is based on principles, such as obligations erga omnes, jus cogens norms and aut dedere aut judicare, but also comes with its own limitations. Chapter VII of the UN Charter also comes with its own rationale, e.g. binding powers of the SC, Article 103 and Purpose and Principles of the UN. These two 'conceptions' of the exercise of criminal jurisdiction by the ICC over non-party States present fundamental differences when confronted with other norms of international law (such as immunity of States officials) or human rights law (such as the principle of legality). Moreover, while the 'universal jurisdiction conception' is based on universality and equal application of the law, the 'Chapter viI conception' is tainted by selectivity.

This book invites the reader to reflect on which 'conception' of a referral under 13 (b) they support, and to then visualize how this 'conception' interacts with other norms of international law. If this interaction is based on genuine assessment of an accumulation of norms, use of conflict-avoidance techniques, application of conflict resolution rules, and, eventually, acceptance that a certain conflict cannot be resolved, then this conception should be the one adopted to understand the 'concept' of a referral under Article 13 (b) Rome Statute. On the other hand, if a 'conception' misuses legal reasoning in order to avoid an irresolvable norm conflict, then this 'conception' should be discarded.

224 The Court also has its own rules of procedure and evidence but this will not be covered in this book.

225 Cryer, “Another Round?," 981. 